\title{
Inheritance of Resistance to Bean Golden Mosaic Virus in Common Bean
}

\author{
Jose J. Velez and Mark J. Bassett ${ }^{1}$ \\ Horticultural Sciences Department, Institute of Food and Agricultural Sciences, University of Florida, \\ Gainesville, FL 32611
}

James S. Beaver and Albeiro Molina

Department of Agronomy and Soils, University of Puerto Rico, Mayaguez, PR 00681

AdDitional InDEx words. Phaseolus vulgaris, RAPD markers

\begin{abstract}
The inheritance of resistance to bean golden mosaic virus (BGMV) in common bean (Phaseolus vulgaris L.) was studied in crosses between susceptible bean variety XAN176 and resistant breeding lines 9236-6 (T446/A429) and 924594 (DOR303/T968). Disease response data were taken on plants from four generations derived from each cross (parents, $F_{1}, F_{2}$, and backcrosses (BCs) of $F_{1}$ to both parents) at 25 days after plants were inoculated with BGMV, using whiteflies (Bemisia argentifolii Bellows \& Perring) as vectors. The segregation ratios obtained from $\mathrm{F}_{2}$ and $\mathrm{BC}$ generations were consistent with the hypothesis that resistance in 9236-6, which prevents a chlorotic response, is conferred by a single recessive gene. The disease response in 9245-94 was controlled by two genes-a dominant gene controlling a dwarfing reaction and a recessive resistance gene preventing a chlorotic response to BGMV infection. An allelism test demonstrated that the gene controlling resistance in 9236-6 is nonallelic with the recessive gene controlling resistance in 9245-94. The gene symbol $\mathbf{b g m}$ is proposed for the recessive resistance gene (originally from A429) in 9236-6. The gene symbol bgm-2 is proposed for the recessive resistance gene (originally from DOR303) in 9245-94.
\end{abstract}

Bean golden mosaic virus (BGMV) is the most devastating viral disease of common bean (Phaseolus vulgaris) in all tropical and subtropical areas where the crop is grown (Faria et al., 1991; Morales and Niessen, 1988). BGMV is transmitted in a persistent manner by the sweetpotato whitefly (Bemisia tabaci, Genn.) and the silverleaf whitefly (Bemisia argentifolii), the latter formerly biotype B of B. tabaci (Gálvez and Morales, 1989). BGMV was first described by Costa (1976), and since then several isolates have been sequenced: BGMV-PR from Puerto Rico (Howarth et al., 1985), BGMV-BZ from Brazil (Gilbertson et al., 1993), BGMV-DR from the Dominican Republic, and BGMV-GA from Guatemala (Faria et al., 1990). BGMV recently moved into southern Florida and has devastated snap, cranberry, and pole bean production. The DNA nucleotide sequence similarity of the BGMV$\mathrm{H}$ (from Homestead, Fla.) and the Caribbean BGMV isolates, based on hybridization and preliminary sequence comparisons, has led to speculations that BGMV was introduced into Florida by hurricane Andrew in 1992 (Blair et al., 1995).

Many different sources of genetic resistance exist and have been used to develop BGMV-resistant varieties. The expression of BGMV may vary among environments. This has been attributed to differences in the BGMV isolates (Gilbertson et al., 1991), the whitefly biotypes (Brown and Bird, 1992), or other genotype $\times$ environment interactions (Morales and Niessen, 1988).

Two gene pools exist in P. vulgaris: the Middle American and the Andean (Gepts and Bliss, 1985). Typical Middle American genotypes include the black, small red, pink, white, and pinto seed classes; whereas Andean genotypes include the large-seeded kidney, red mottled, and snap bean seed classes. Hybridization is easily achieved between the gene pools, but lethal $F_{1}$ hybrid and other genetic barriers exist (Singh et al., 1991). The most useful

Received for publication 14 Apr. 1997. Accepted for publication 17 Nov. 1997 Florida Agricultural Experiment Station journal series no. R-05556. The cost of publishing this paper was defrayed in part by the payment of page charges. Under postal regulations, this paper therefore must be hereby marked advertisement solely to indicate this fact.

To whom reprint requests should be addressed. sources of BGMV resistance have been from Middle American races and have been more important in the improvement of other Middle American genotypes (Morales and Singh, 1991).

A breeding program at Centro Internacional de Agricultura Tropical (CIAT) to select for BGMV resistance has been in progress since 1975. Germplasm was extensively evaluated in the greenhouse and in the field in Guatemala (CIAT, 1982). After $\approx 16$ years of work, several sources of resistance were found in different seed classes and gene pools (Beebe and Pastor Corrales, 1991). Some of the most important sources of resistance or (breeding lines) for two market classes were as follows: 1) the black-seeded Middle American varieties ICA-Pijao (ICTA-Jutiapa), (ICTATamazulapa), (ICTA-Quetzal), (ICTA-Ostua), (Negro Huasteco), Turrialba I and Porrillo Sintético; and 2) the small red, Middle American varieties (DOR364), (DOR391), (DOR475), (DOR482), and Garrapato. Those varieties display reduced mosaic, diffuse mottling, and superior yield (Beebe and Pastor Corrales, 1991). According to Morales and Niessen (1988), the most resistant breeding lines, in seed classes other than black and small red varieties developed by CIAT, are A429 (pinto) and DOR303 (red kidney).

Blair and Beaver (1993) reported that a single recessive gene in A429 expressed a type of resistance that can best be described as high tolerance; i.e., infected plants express either no chlorosis or mild, light-green chlorosis. Flowering and pod set are almost normal, but pods are often deformed. Blair et al. (1993) studied the inheritance of a dwarfing response to BGMV in DOR 303, regarding the dwarfing response as a type of resistance to BGMV. The hypothesis that two recessive genes (duplicate dominant epistasis) controlled the dwarfing fit the observed segregation of 15:1 for chlorotic to dwarfed, respectively. Both studies (Blair and Beaver, 1993; Blair et al., 1993) were limited to analysis of $F_{1}$ and $F_{2}$ data and lacked the independent test that backcross $(\mathrm{BC})$ generations provide. Also, the timing of inoculation and the vector were not controlled. The objective of this paper was to study the inheritance of resistance to BGMV from breeding lines with resistance to BGMV derived from either A429 or DOR303 under more controlled experimental conditions. 


\section{Materials and Methods}

Plant Material, A429 and DOR303 have resistance to BGMV obtained from crosses between lines with various levels of tolerance or resistance such as the tolerant 'Porrillo Sintético' and chlorosis resistant 'Garrapato'. A429 [Garrapato X (Porrillo Sintético $\times$ G02115)] when infected expresses very mild, attenuated symptoms. Infected plants show limited vein chlorosis, resulting in faint, light-green mottling and acceptable yield (Morales and Niessen, 1988). Because A429 has poor seed quality of the pinto market class and is late flowering, it has not been released as a variety (Blair and Beaver, 1993). DOR303 [Porrillo Sintético/ Cacahuate 72//(Moeba/Cacahuate 72)///Redkloud] shows strong dwarfing response under BGMV pressure; i.e., the stem tip and lateral shoots are stunted and distorted and almost all growth is inhibited. Infected leaves express little or no chlorosis; instead they are rugose, small, thick, and dark green.

Bean breeding lines A429 and DOR303 were crossed with pinto breeding line T446 or light red kidney breeding line T968, respectively, which possess high yield potential in the tropics. The parental sources of resistance-9236-6 (T446/A429) and 9245-94 (DOR303/T968) - were developed from the indicated crosses by inbreeding and selection for homozygous resistance to BGMV. Lines 9236-6 and 9245-94 were crossed with XAN176, a susceptible genotype that uniformly expresses bright golden chlorosis across the leaf lamina. Plants of four generations (parents, $F_{1}, F_{2}$, and $\mathrm{BCs}$ of $\mathrm{F}_{1}$ to both parents) from each cross were inoculated with whiteflies following the methodology developed by Adames et al. (1996).

An $\mathrm{F}_{2}$ seed lot (Code GV 10627) was developed at CIAT from the cross Turbo III ((XAN132 x Garrapato) $\times$ (DOR303 $\times$ RXAH18274-C)). An $F_{2}$ population of 135 plants from this cross was grown at Mayaguez, P.R., and inoculated with whiteflies following the methodology developed by Adames et al. (1996), which is a greenhouse procedure for inoculation of bean plants with BGMV described below.

Grennhouse inoculations. The whitefly inoculations were conducted in two greenhouses at the Mayaguez campus of the University of Puerto Rico. One of the greenhouses was used to maintain an aviruliferous whitefly colony on soybeans (Glycine $\max , \mathrm{L}$. Merr), where the soybeans were replanted every $10 \mathrm{~d}$ to ensure that the colony was maintained on young plants. This greenhouse was maintained free of BGMV and was also used to germinate the bean lines to be evaluated. The other greenhouse contained the source of BGMV and was maintained free of whiteflies. The virus was maintained in BGMV-susceptible snap bean ( $P$. vulgaris 'Top Crop') plants still in the vegetative stage of development. In a large chamber (cage), aviruliferous whiteflies were allowed to feed for $3 \mathrm{~d}$ on plants that clearly expressed BGMV symptoms. To inoculate experimental plant materials, 30 viruliferous whiteflies were transferred from the large chamber to the small cage that covered each pot of experimental material, each containing three 10-d-old (postplanting) bean plants (V2 stage). After $3 \mathrm{~d}$ of whitefly feeding, the small cages were removed from the pots and all whiteflies were killed with an insecticide (Orthene).

Two experiments were conducted from 12 May to 23 Aug. 1994 with the populations derived from 9236-6 and 9245-94 crossed with XAN176. Each experiment consisted in 50 pots, each with 3 plants, that were planted and distributed on benches: parents $(4$ pots each), $F_{1}$ ( 3 pots), $F_{2}$ (21 pots), $B C$ (to susceptible parent) $F_{1}$ (4 pots), and $\mathrm{BC}$ (to resistant parent) $\mathrm{F}_{1}$ (14 pots). A third experiment was conducted during September 1995 with the $F_{2}$ from Turbo III ((XAN132 X Garrapato) X (DOR303 x RXAH18274-C)) consisting of 50 pots, each with 3 plants: $\mathrm{F}_{2}$ (45 pots) and 'Top Crop' susceptible control (5 pots). The inoculated plants were maintained at an average temperature of $27{ }^{\circ} \mathrm{C}$ and relative humidity of $75 \%$. Each inoculated plant was evaluated for the presence or absence of chlorosis and dwarfing symptoms and classified for its reaction. Plants were evaluated at 10,15,20, and $25 \mathrm{~d}$ after inoculation. The observed frequency of plants with chlorotic or dwarfed symptom reaction classes was tested by a chisquare test for goodness of fit (Steel and Torrie, 1980).

Allelism TEST. Evidence is presented below demonstrating that A429 and DOR303 each carry a recessive resistance gene conferring a nonchlorotic response to BGMV infection. To test for allelism between the two recessive resistance genes conferring the nonchlorotic response to $\mathrm{BGMV}$, a separate experiment was conducted under the same cultural conditions described above. Twelve $F_{1}$ plants from the cross DOR303 x A429 and four plants of each parent were grown with one plant per pot and inoculated with BGMV. Each plant was evaluated 10, 20, and $40 \mathrm{~d}$ after inoculation.

\section{Results and Discussion}

INHERITANCE OF 9236-6 RESISTANCE FROM A429. The inoculation technique resulted in $100 \%$ infection of susceptible parental plants and uniform timing of symptom expression. XAN176 plants were uniformly chlorotic; i.e., chlorosis was spread throughout the leaf lamina, whereas chlorosis was absent from $9236-6$ plants. The $F_{f}$ plants showed the chlorotic symptoms equivalent to the reaction of XAN176 (Table 1). The observed segregation in the $F_{2}$ fit a 3:1 ratio of susceptible (chlorotic) to resistant (nonchlorotic), respectively (Table 1). The observed data fit the hypothesis that resistance of 9236-6 is controlled by a single recessive gene. Susceptibility was completely dominant since a heterozygous class with intermediate chlorosis was not observed in the $F_{1}$ or $F_{2}$ generations. The progeny of the backcross to the susceptible parent $\left(\mathrm{F}_{1} \mathrm{x}\right.$ XAN176) showed the chlorotic symptoms equivalent to the XAN176 reaction (Table 1). The observed segregation in the backcross to the resistant parent $\left(F_{1} \times 9236-6\right)$ fit a 1:1 ratio of susceptible (chlorotic) to resistant (nonchlorotic) plants (Table 1). The observed results in the backcross progeny confirm the hypothesis that resistance to BGMV in $9236-6$ is controlled by a single recessive gene. Previous studies (Blair and Beaver, 1993) showed a similar response to the genotype $\mathrm{A} 429$, but only parental and $\mathrm{F}_{2}$ populations were tested. All data in Table 1 àre consistent with the hypothesis that resistance to BGMV in 9236-6 is controlled by a single recessive gene, for which the symbol bgm is proposed. This gene symbol was previously proposed tentatively by Urrea et al. (1996) for the resistance gene in A429.

INHERITANCE OF 9245-94 RESISTANCE FROM DOR303. The inoculation technique resulted in $100 \%$ infection; i.e., all susceptible parental plants tested developed the first symptoms 10 to $12 \mathrm{~d}$ after inoculation. XAN176 plants became uniformly chlorotic and 9245-94 plants were completely dwarfed, with very faint chlorotic symptoms. At $25 \mathrm{~d}$ after inoculation, the $\mathrm{F}_{1}$ plants were dwarfed and chlorotic (Table 2). In some plants, some shoots were stunted but not chlorotic, while other shoots had fully expanded chlorotic leaves. The $\mathrm{F}_{2}$ segregation fit a ratio of 9:3:3:1 for the classes chlorotic and dwarfed, nonchlorotic and dwarfed, chlorotic and nondwarfed, and asymptomatic (nonchlorotic and nondwarfed), respectively (Table 2 ). The observed data fit the hypothesis that resistance from 9245-94 is controlled by two genes, a dominant gene for the dwarfing reaction and a recessive gene for the nonchlorotic reaction. Segregation in the progeny of the backcross 
Table 1. Classification of parental, $\mathrm{F}_{1}, \mathrm{~F}_{2}$, and backcross (BC) generations of common bean progeny from the cross XAN176 (susceptible) $\times$ 9236-6 (resistant) for resistance to bean golden mosaic virus (BGMV) $25 \mathrm{~d}$ after inoculation. ${ }^{\mathrm{z}}$

\begin{tabular}{lccccc}
\hline & \multicolumn{2}{c}{ BGMV symptom reaction } & & Expected & \\
Generation & Chlorotic & Nonchlorotic & ratio & $\chi^{2}$ & \\
\hline XAN176 (susceptible) & 12 & 0 & & & \\
$9236-6$ (resistant) & 0 & 24 & & 0.307 & 0.58 \\
$F_{1}$ & 12 & 0 & $3: 1$ & \\
$F_{2}$ & 96 & 27 & $1: 0$ & 0.05 \\
BC $\left(F_{1} \times\right.$ XAN176) & 24 & 0 & $1: 1$ & 0.88 \\
BC $\left(F_{1} \times 9236-6\right)$ & 43 & 41 & & \\
\hline
\end{tabular}

2The genetic hypothesis is that $9236-6$ carries a recessive resistance gene (bgm) for BGMV.

yInitial symptoms included mottling and fine vein-limited yellow lines; later, intense foliar yellowing (chlorosis) spread across the leaf lamina.

( $\left.F_{1} \times X A N 176\right)$ to the susceptible parent fit a ratio of 1 chlorotic and dwarfed to 1 chlorotic and nondwarfed-evidence of a dominant gene for dwarfing carried by $9245-94$ (Table 2). The segregation in the progeny of the backcross $\left(F_{1} \times 9245-94\right)$ to the resistant parent fit a ratio of 1 chlorotic and dwarfed to 1 nonchlorotic and dwarfed-evidence of a recessive gene for resistance to chlorosis carried by $9245-94$ (Table 2). Those results differ from the results of Blair et al. (1993), in which the dwarfing reaction fit a genetic model involving two recessive genes. At $25 \mathrm{~d}$ after inoculation in their $F_{2}$ population derived from 'Indeterminate Jamaica Red' $x$ DOR303 (and reciprocal), the segregation ratio was 15:1 for chlorotic and nondwarfed to nonchlorotic and dwarfed, respectively. Our $\mathrm{BC}$ test results (Table 2) confirm the hypothesis that a single dominant gene (schematic symbol $D w f$ ) controls dwarfing and an independent recessive gene (schematic symbol bgm-2) controls the nonchlorotic reaction to BGMV. The largest phenotypic class-chlorotic and dwarfed-has the genotype Dwf/- Bgm-2/-, showing that the dominant dwarfing gene gives no protection against chlorosis. In retrospect, the $D w f$ gene is not really a BGMV-resistance gene because the stunting of growth has neither economic value nor apparent protective value against BGMV. The gene combination Dwf bgm-2 in DOR303 created the illusion that dwarfing had protective value against chlorosis. No formal gene symbol is proposed for the dwarfing reaction gene, which the results of Blair et al. (1993) demonstrate may possibly give different expression in different genetic backgrounds. The question remains whether the schematic $b g m-2$ may be allelic with $b g m$.

ALLELISM TEST FOR RECESSIVE BGMV RESISTANCE GENES. All the inoculated $F_{1}$ and DOR303 plants developed symptoms within 10 $\mathrm{d}$ after inoculation. Infected DOR303 plants showed severe dwarf- ing. The inoculated A429 plants expressed none of the typical BGMV symptoms. At $10 \mathrm{~d}$ after inoculation, $\mathrm{F}_{1}$ plants from the cross DOR303 x A429 showed limited chlorosis, which consisted of faint light green mottling (data not shown). At $20 \mathrm{~d}$ after inoculation, $F_{1}$ plants showed typical BGMV-susceptible symptom expression, viz., bright golden chlorosis spread across the leaf lamina. At $40 \mathrm{~d}$ after inoculation, $F_{1}$ plants presented strong chlorotic symptom expression, shoot stunting, and flower abortion. Those data demonstrate the nonallelic response of complementation due to the existence of two different recessive genesbgm from A429 and bgm-2 from DOR303-for the nonchlorotic reaction to $B G M V$ infection. The $F_{1}$ expresses chlorosis because it has the genotype Bgm/bgm Bgm-2/bgm-2.

Another line of evidence supports the hypothesis that DOR 303 does not have the bgm gene from A429. Urrea et al. (1996) reported the development of a codominant randomly amplified DNA (RAPD) marker ( $\mathrm{R} 2_{570 / 530}$ ) for the $b g m$ gene. Using this RAPD marker in a survey of germplasm, they found that DOR303 had the homozygous susceptible reaction; i.e., bgm was not detected by $\mathrm{R} 2_{570 / 530}$ (Urrea et al., 1996). That result is consistent with the nonallelic response from the test cross DOR303 x A429 described above.

A third source of support for the hypothesis that DOR303 does not have the $\mathrm{bgm}$ gene from A429 is derived from evaluation of an $\mathrm{F}_{2}$ population developed by CIAT from the cross Turbo III ((XAN132 x Garrapato) x (DOR303 x RXAH18274-C)). Evidence presented above has already established that 9236-6 (via A429 and Garrapato) carries bgm and 9245-94 (via DOR303) carries a nonallelic gene tentatively designated $\mathrm{bgm}-2$, which also confers resistance to chlorosis after BGMV inoculation. In the $F_{2}$ from a cross between Turbo III and another parent with Garrapato

Table 2. Classification of parental, $F_{1}, F_{2}$, and backcross $(B C)$ generations of common bean progeny from the cross $9245-94$ (resistant) $\times$ XAN176 (susceptible) for resistance to bean golden mosaic virus (BGMV) $25 \mathrm{~d}$ after innoculation. ${ }^{\mathrm{Z}}$

\begin{tabular}{|c|c|c|c|c|c|c|c|}
\hline \multirow[b]{2}{*}{ Generation } & \multicolumn{4}{|c|}{ BGMV symptom reaction } & \multirow[b]{2}{*}{$\begin{array}{c}\text { Expected } \\
\text { ratio }\end{array}$} & \multirow[b]{2}{*}{$\chi^{2}$} & \multirow[b]{2}{*}{$P$} \\
\hline & $\begin{array}{l}\text { Chlorotic } \\
\text { dwarfed }^{y}\end{array}$ & $\begin{array}{c}\text { Nonchlorotic } \\
\text { dwarfed }^{x}\end{array}$ & $\begin{array}{c}\text { Chlorotic } \\
\text { nondwarfed }\end{array}$ & $\begin{array}{c}\text { Nonchlorotic } \\
\text { nondwarfed }\end{array}$ & & & \\
\hline XAN176 & 0 & 0 & 23 & 0 & & & \\
\hline $9245-94$ & 0 & 24 & 0 & 0 & & & \\
\hline $\mathbf{F}_{1}$ & 11 & 0 & 0 & 0 & & & \\
\hline $\mathbf{F}_{2}$ & 61 & 24 & 24 & 1 & $9: 3: 3: 1$ & 3.208 & 0.39 \\
\hline $\mathrm{BC}\left(\mathrm{F}_{1} \times \mathrm{XAN} 176\right)$ & 10 & 0 & 11 & 0 & $1: 1$ & 0.048 & 0.83 \\
\hline $\mathrm{BC}\left(\mathrm{F}_{1} \times 9245-94\right)$ & 37 & 34 & 0 & 0 & $1: 1$ & 0.072 & 0.83 \\
\hline
\end{tabular}

${ }^{2}$ The genetic hypothesis is that $9245-94$ carries two genes, a dominant gene for the dwarfing reaction and a recessive gene (bgm-2) for the nonchlorotic response.

yPlant shoots were either dwarfed but not chlorotic, or had fully expanded chlorotic leaves.

xPlants showed a strong dwarfing response, in which shoots were stunted and distorted. Leaves expressed no cholorosis, but instead were rugose, thick, and dark green. 
Table 3. Classification of the $\mathrm{F}_{2}$ population from the cross Turbo III ((XAN132 x Garrapato) $\times$ (DOR303 $\times$ RXAH18274-C)) for resistance to bean golden mosaic virus (BGMV) at $25 \mathrm{~d}$ after inoculation.

\begin{tabular}{lcccc}
\hline \multicolumn{2}{c}{ BGMV symptom reaction } & \multicolumn{2}{c}{} & \\
& Nonchlorotic & $\chi^{2}$ & $\chi^{2}$ & $P$ \\
\hline Chlorotic & 51 & ratio & 1.96 & 0.16 \\
\hline 4 & & $9: 7$ & 11.76 & 0.001 \\
\hline
\end{tabular}

and DOR303 in its pedigree, the BGMV resistance segregation fit a 9:7 ratio for chlorotic to nonchlorotic, respectively (Table 3). A test of the 3:1 ratio for the same data gave a highly significant deviation from that hypothesis. The observed fit to a $9: 7$ ratio is consistent with the hypothesis that the parent ((XAN132 $\mathrm{x}$ Garrapato) $\times($ DOR303 $\times$ RXAH18274-C)) carries the double recessive genotype $b g m b g m-2$, each gene derived from its expected source. Therefore, the gene symbol $b g m-2$ is proposed for the recessive resistance gene in DOR303.

In summary, the 9236-6 parent, which has BGMV resistance derived from A429, carries a single recessive gene $\mathrm{bgm}$ that confers resistance to the chlorosis-inducing effects of BGMV infection. These results agree with the results of Blair and Beaver (1993) and confirm them with BCtests. The 9245-94 parent, which has BGMV resistance derived from DOR303, carries two genes. The first gene produces a dwarfing response after inoculation with $\mathrm{BGMV}$, but gives no protection against chlorosis. The second gene confers a recessive resistance to the chlorosis inducing effects of BGMV infection, but has no dwarfing response. An allelism test cross, DOR $303 \times$ A 429, demonstrated complementation in the $F_{1}$ plants (leaf chlorosis) with respect to $\mathrm{bgm}$ and similar recessive resistance gene in DOR303. The work of Urea et al. (1996) demonstrated that DOR303 does not carry $\mathrm{bgm}$; and, therefore, a nonallelic gene must express the chlorosis resistance found in DOR303. The $\mathrm{F}_{2}$ from the cross Turbo III ((XAN132 x Garrapato) $\times($ DOR303 $x$ RXAH18274-C)) fit a segregation ratio of 9:7 (susceptible to resistant) as expected if DOR303 carries a recessive resistance gene that is nonallelic with the one in Garrapato. Those results support the hypothesis of nonallelism, and the gene symbol bgm-2 is proposed for the recessive gene in DOR303 conferring protection from chlorosis induced by BGMV infection. The dominant gene in DOR303 that produces dwarfing response to BGMV infection appears to provide no protection against BGMV. However, if the dwarfing response is accompanied by a great reduction in the replication of BGMV in the infected plant, there may be some epidemiological protection for the host population of bean plants. The latter hypothesis was not investigated.

\section{Literature Cited}

Adames, C., J.S. Beaver, and O. Diaz. 1996. Una metodologia para evaluar en el invernadero el mosaico dorado de la habichuela. J. Agr. Univ. Puerto Rico 80:65-72.

Beebe, S. and M.A. Pastor Corrales. 1991. Breeding for disease resistance, p. 561-617. In: A. van Schoonhoven and O. Voysest (eds.). Common beans, research for crop improvement. C.A.B. Intl., London.

Blair, M.W., M.J. Bassett, A.M. Abouzid, E. Hiebert, J.E. Polston, R.T. Mcmillan, Jr, W. Graves, and M. Lamberts. 1995. Occurrence of bean golden mosaic virus in Florida. Plant Dis. 79:529-533.
Blair, M.W. and J.S. Beaver. 1993. Inheritance of bean golden mosaic virus resistance from bean genotype A429. Annu. Rpt. Bean Improv. Coop. 36:143.

Blair, M.W., J.S. Beaver, and C. Adames. 1993. Inheritance of the dwarfing response to bean golden mosaic virus infection in dry beans (Phaseolus vulgaris, L). Annu. Rpt. Bean Improv. Coop. 36:144-145. Brown, J.K. and J. Bird. 1992. Whitefly-transmitted geminiviruses and plant associated disorders in the Americas and the Caribbean Basin. Plant Dis. 76:220-225.

Centro Internacional de Agricultura Tropical. 1982. Bean program annual report. CIAT, Cali, Colombia.

Costa, A.S. 1976. Whitefly-transmitted plant diseases. Annu. Rev. Phytopathol, 14:429-449.

Faria, J.C., R.L. Gilbertson, F.J. Morales, G. Russell, P. Ahlquist, S.F. Hanson, and D.P. Maxwell. 1990. Sequence of infectious clones of two mechanically transmissible isolates of bean golden mosaic geminivirus Phytopathology 83:709-715. (Abstr.)

Faria, J.C., M.J.Zimmermann, and M. Yokoyama. 1991. Development of Phaseolus vulgaris L. tolerant to bean golden mosaic virus. Annu. Rpt. Bean Improv. Coop. 34:11-12.

Gálvez, G.E. and F.J. Morales. 1989. Whitefly-transmitted viruses, p. 379-406. In: H.F. Schwartz and M.A. Pastor Corrales (eds.). Bean production problems in the tropics. 2nd ed. Centro Internacional de Agricultura Tropical, Cali, Colombia.

Gepts, P. and F.A. Bliss. 1985. F hybrid weakness in the common bean: Differential geographic origin suggests two gene pools in cultivated bean germplasm. J. Hered. 76:447-450.

Gilbertson, R.L., S.H. Hidayat, R.T. Martinez, S.A. Leong, J.C. Faria, F. Morales, and D.P. Maxwell. 1991. Differentiation of bean-infecting geminivus by nucleic-acid hybridization probes and aspects of bean golden mosaic virus in Brazil. Plant Dis. 75:336-342.

Gilbertson, R.L., J.C. Faria, P. Ahlquist, and D.P. Maxwell. 1993. Genetic diversity in geminivirus causing bean golden mosaic virus disease: The nucleotide sequences of the infectious cloned DNA components of a Brazilian isolate of bean golden mosaic geminivirus. Phytopathology 83:709-715.

Howarth, A.J., J. Canton, M. Bossert, and R.M. Goodman. 1985. Nucleotide sequence of bean golden mosaic virus and a model for gene regulation in geminiviruses. Proc. Natl. Acad. Sci. USA 82:3572-3576.

Morales, F.J. and A.I. Niessen. 1988. Comparative responses of selected Phaseolus vulgaris L. germplasm inoculated artificially and naturally with bean golden mosaic virus. Plant Dis. 72:1020-1023.

Morales, F.J. and S.P. Singh. 1991. Genetics of resistance to bean golden mosaic virus in Phaseolus vulgaris L. Euphytica 52:113-117.

Singh, S.P., P. Gepts, and D.G. Debouck. 1991. Races of common bean (Phaseolus vulgaris L. Fabaceae). Econ. Bot. 45:379-396.

Steel, R.G.B. and H.H. Torrie. 1980. Principles and procedures of statistics. McGraw-Hill, New York.

Urrea, C.A., P.N. Miklas, J.S. Beaver, and R.H. Riley. 1996. A codominant randomly amplified polymorphic DNA (RAPD) marker useful for indirect selection of bean golden mosaic virus resistance in common bean. J. Amer. Soc. Hort. Sci. 121:1035-1039. 